\title{
НАСПРАМНА СЛИКА РУСИЈЕ КАО ХРОНОТОП У КЕЛМАНОВОМ ИСТОРИЈСКОМ РОМАНУ МАПИРАЬЕ СВЕТА
}

Настанак дефиниција књижевнотеоријских појмова допринео је, према одговарајућој, националној филолошкој традицији, стварању различитих терминолошких решења. Језички, појмовање се ставља у одређену културну традицију. Немачки појам 'наспрамних слика' (Gegenbilder) насталих на основу идеја, које су се рађале током векова као последица историјског искуства, садржаје о којима говори ставља у однос према стварности, независно од времена и простора. За разлику од тога, Бахтинов појам 'хронотопа,' спајајући ове две категорије, законитошћу простора и времена указује на културно иманентне садржаје. Анализом романа Maпирање света (Die Vermessung der Welt, 2005) аутора Данијела Келмана, рад истражује однос немачке културе према руској и поставља питање интеркултуралне компетенције у дихотомији између овде претенциозно пројектованог германског и словенског света.

Кључне речи: Бахтин, интеркултурална компетенција, историјски роман, Келман, Мапирање света, наспрамне слике, суочавање с прошлошћу, хронотоп.

The emergence of definitions of literary-theoretical terms according to the relevant philological tradition has contributed to the creation of various terminological solutions. Linguistically, terms are classified in a specific cultural tradition. As a result of historical experience, the German concept of counter-images relates the content referred to with reality, regardless of time and space. In contrast, Bakhtin's term "chronotope", which combines these two categories, points to culturally immanent content through the regularity of space and time. By analyzing the novel Measuring the World (Die Vermessung der Welt, 2005) by Daniel Kehlman, the paper examines the relationship between German and Russian culture and questions intercultural competence in the dichotomy between the Germanic and the Slavic world.

Keywords: Bakhtin, chronotope, coping with the past, counter-images, historical novel, intercultural competence, Kehlman, Measuring the World.

\section{1. Појам и дефиниција 'наспрамних слика'}

У теорији књижевности на немачком говорном подручју широко је распрострањено коришћење термина 'наспрамних слика,' (Gegenbilder) односно супротстављање идеја. На тај начин, поступци стварања контраста отварају могућност препознавања значења наговештавањем и истовремо указују на дистинкције помоћу разграничавања идеја или пак супротстављањем контраста. Описујући још срењовековну књижевност, Јоахим Бумке (Joachim Bumke) je замену постојећих друштвених односа у стварности са супротно конципираним у књижевном дискурсу први назвао „концепцијом очигледно супротстављене стварности коју треба на исти начин и тумачити.“ (1986: 12)

Идеја о разликовању реално владајућих друштвених односа у одређеном тренутку од оних који се пројектују њиховим преиспитивањем помоћу поступка 
стварања контраста, подразумева заправо различита значења. За време барока, контрапозиције у односу на друштво у немачкој књижевности долазе до изражаја креирањем књижевнних типова попут пикара, хвалисавца брамарбаса или галантома (Galanthomme, џентлмен). Заједничка карактеристика им је однос према стварности, констелација интерактивног обликовања 'изврнутих слика' у поређењу са социјалном стварношћу. Врхунац, на овај начин обликованог јунака, светлу тачку представља лик Шелмуфски (Schelmuffsky) Кристијана Pојтера (Christian Reuter) у роману Шелмуфскијев заиста чудесан и врло опасан путопис по води и земљи (Schelmuffskys warhafftige curiöse und sehr gefährliche Reisebeschreibung zu Wasser und Lande). Ројтеров новитет се огледа у перспективи преломљеног одраза, коју изазива улога протагонисте. ${ }^{1}$

Кроз историју немачке књижевности, идеја о представљању друштвене кохезије може у даљем току да се прати кроз грађење антагонистичких односа, које се у савременој немачкој књижевности преносе из раздобља у разобље. У појединим покретима просветитељства, као што су то штурм и дранг или њему блиски савез песника окупљених у гетингеншком гају (Göttinger Hainbund), аргументација заснована на постулату природног права славила је идеал природе, који је програмски служио за приказ идеја, супротних од оних за које се залагао апсолутистички режим. Полазиште чиниле су идеје Кристијана Волфа (Christian Wolff) које су допринеле схватању постојања права на живот или слободу независно од произвољног исказивања божје или кнежевске милости. Потом, у раној фази романтизма, Новалис није сматрао средњи век мрачним раздобљем, него временом које чува поезију. Средњи век њему служи као песничка слика пројектована наспрам вредности владајућег времена, доживљеног као прозаичног.

Почетком 19. века у песмама, бајкама и сагама "немачка шума“је постала узвишена метафора. Историјске расправе и расправе о народном фолклору исту проглашавају симболом германског и немачког бића и културе или сликом која је пројектована насупрот урбаној средини у Француској, као нпр. код Хајнриха Хајнеа и Госпође де Стал. Такође, роман, на пример, Теодора Шторма (Theodor Storm) Ханс и Хајни Кирх (Hans und Heinz Kirch, 1883) из периода реализма, у наративном дискурсу оптужује оца за недовољно залагање за породицу и заступање анахроних идеја у вези са фамилијом, па се, према томе, идеја породичне идиле пројектује наспрам оне која се у историографији еуфемистички одомаћила у синтагми ,раздобља социјалних питања“" (Zschaler 2012: 100-101).

Међутим, у термину немачких 'наспрамних слика' садржано је још једно додатно значење. Ово је, онако како се то у литератури данас може пронаћи, резултат дугог процеса, трајних друштвених сукоба и подела унутар немачке језичке заједнице. Процесу је допринео, пре свега, прелазни период из 18. у 19. век, као и појава паралелно два књижевна раздобља, вајмарске класике и романтизма. Тада, у оштрим расправама између присталица једног и другог правца, формулишу се основна начела етичког вредновања у односу на традиционалне садржаје. Фридрих Шлегел своју дефиницију романтичне ироније (2013)

${ }^{1}$ О књижевном типу који у изврнутој слици формира контратип вид. у: Вукчевић, М. М. 
црпио је из дискусије око питања да ли техника романтичне ироније служи објективном приказивању одеређеног уметничког дела или исто сагледава као производ субјективне воље. Романтичну иронију није могуће у потпуности одвојити од поступка разбијања естетске илузије нити је једноставно изједначити са њим. Шлегелово схватање ироније је, пре свега, симболичко и филозофско, дакле, не реторичко, него дефинисано према Сократу. Иронија не преноси утврђено знање, него тежи властитој рефлексији у наизменичном току питања и одговора. Према Шлегелу, ,заокружена иронија престаје бити иронија и постаје озбиљна“ (1981: 144). Своју комичну карактеристику иронични хумор стиче тако што себе преиспитује и у трајном остваривању самокритике постиже виши степен озбиљности. Или, како Шлегел каже, „у оном изворном Сократовом смислу (...) иронија не значи баш ништа друго него оно чуђење духа који размишља о себи, што се често претвара у тихо осмешивање“ (1830: 61). Иронија, у овом контексту, долази до изражаја приликом ауторефлексивног размишљања, размишљања о властитом бићу и сопственим поступцима, што посматрано у вези успостављеној са поступком стварања наспрамних слика, отвара могућност доношења закључка како о немачком хумору тако и о односу који немачка култура гаји према њој страној култури.

\section{2. Немачки идентитет и Хумболтово путовање за Русију}

Према пажњи која се у секундарној литератури поклања Келмановом роману и историјском контексту времена у које је смештена радња романа (Olesko 2007), као и историјски реалним личностима, испоставља се да су актуелни друштени односи, дефинисани као производ историјских догађаја, разлог за Келманово истраживање жанра историјског романа. ${ }^{2}$ Историјски романи дају историчарима прилику да критички преиспитају готово све што сматрају неупитним: однос између доказа (или онога што нам је познато као чињеница) и историјског писања или, формализовано посматрано према Катрини Олеско, однос између историјске епистемологије и наративне структуре (Olesko 2007: 761).

Тематизовањем сусрета Александра фон Хумболта и Карла Фридриха Гауса на 17. конгресу Друштва немачких истраживача природе и лекара (Gesellschaft Deutscher Naturforscher und Ärzte) 1828. године у Берлину, који је Гаус посетио на позив Хумболта, роман Мапирање света Данијела Келмана говори о подвизима ова два значајна научника. Он читалаштво упознаје како са културноисторисјски значајним периодом у немачкој историји тако и са карактеристикама које су допринеле изградњи културног идентитета немачког народа. Иако се однос између два научника, у роману приказан превенствено кроз причу њихове писмене размене, гради референцама на оба Хумболтова путовања, прво за Јужну Америку затим и за Русију, секундарна литература се на ово друго посебно не осврће. Латинска Америка се посматра, између осталог, као историјски простор у процесу детериторизације, лишен своје јединствености интегрисањем у нове мапе које је сачинио колонијализам и глобални капитали-

2 О Келмановом роману Мапирање света као историјском роману детаљније код: Вукчевић, М. М. "Хумболтов сусрет са Амазонијом. Магични реализам у Келмановом роману Мапирање света“" (2020: 288-290). 
зам (Gerstenberger 2010). У том контексту, културна питања се постављају или у вези са робовласништвом (Holl 2012) или начином вредновања Хумболтових географских открића (Schaumann 2009). Критичке рефлексије на историјску улогу властите културе се препознају у сагледавању успеха научних достигнућа, у „стварању друштвених стереотипа, бављењу сурогатима и екстрактима“ (Еtte 2012: 37). Књижевнотеоријски приступи баве се истраживањем поетике писања фикције у погледу на „наивни реализам“", који је, према Карини Типелскирх, доминирао немачком литературом након 1945. године, али и мрежом интертекстуалних референци од Гетеа до магичног реализма Јужне Америке (Tippelskirch 2009: 194), или, пак, рецепцијом Келмана у контексту латиноамеричке литературе (Rickes 2012). Мада се у литератури секторски релевантних организација тематизује Хумболтово путовање кроз Балтик, потом за Русију и Сибир (Beck 2004), интересовање за Келманов роман у контексту културног контакта источно од немачких насеобина се јавља искључиво у два случаја и то посматрано из угла идеолошког тумачења друштвеног развоја након Другог светског рата (Pizer 2010; Howell 2018), док се перцепција идентификације властитог бића у иностраној литератури налази у сегемнту историјске „борусификације“, односно пруског наслеђа (Grabbe 2014).

Додуше, у секундарној литератури се постављају питања менталитета, карактеристичних црта немачког друштвеног бића, али тек контрастивним приказом разумевања норми друштвеног опхођења у словенској култури ствара се дистинктивно обележје, које употпуњује контекст приказивања немачког бића представљено као пример за властито културно порекло, односно германско порекло. Историјска улога властите културе гради се, најпре, разграничењем унутар западних култура, заснованих на заједничкој латинској традицији. Сећањем на историјску улогу освајача Лопеа де Агиреа, Хумболтова перцепција друштвених односа пројектује одраз дела немачке културе који се у полазишту супротставља културној традицији која је заједничка западној Европи. У културном кругу, дефинисаном у описаним оквирима, Том Кинт историјски идентитет Немаца у Келмановом роману, такође, препознаје у идеји о Немцима, оличену у вези између, како наводи, „величине и комичног израза немачке културе“" (2012: 367).

„Овај жалосни човек не нађе ништа научно, рече Хумболт. Ништа више од тога, птица не истражује ваздух нити риба воду. Или Немац хумор, рече Бонплан. (...) Познаваше Прус смех. У Пруској се много смеје. Треба се сетити само Виландових романа или изврсних комедија Грифијуса. Такође, Хердер знаше да се добро нашали. У то не сумња, рече Бонплан уморно. Онда је добро, рече Хумболт док је чешао крзно псета, раскрвављено убодима инсеката“" (Kehlmann 2008: 111).

У разговору између Хумболта и његовог сапутника Бонплана, пас као тема разговора, симболичком функцијом за верност, служи за постављање питања

${ }^{3}$ У тексту, сви преводи са страних језика су ауторски. Цитати из романа у наставку се наводе само према страницама. 
социјалних врлина. Након што се пас отргао и отрчао, Бонплан констатује да му нема помоћи. Садржаном алузијом на поверење, тако што он „не дозвољава“ (130) нестанак пса, у Хумболтовом одговору Бонплану се успоставља однос поверења, однос који помоћу препознавања ствара реалност. Однос између Хумболта и Бонплана, аналогно односу између Гауса и његовог сина Евгенија, који на крају романа напушта домовину и одлази за Америку, представља заправо немачко-француске односе успостављене после Другог светског рата. Али ако се однос у смислу верности, преслика на браћу Хумболт, на двојбу у немачком бићу данас, након превазиђене послератне поделе државе и народа, онда је у умерености која је резултат солидарности и бриге, односно у умерености браће Хумболт, коју су „увек непогрешиво осећали“ (266), перспектива која се отвара.

Тему двојице „лудих професора“ Келман боји меланхоличном нотом тако што их у њиховој посвећености професионалном, научном позиву извргава руглу (Whitfield 2007: 713). Гаусове невероватне способности и његову одлуку да позивом који је одабрао, као и својим истраживањима, себи остане веран, чак и на штету своје и туђе среће, Витфилд види као разлог зашто се Гаус одвојио од друштва, а тупавост других доживљава као терет. За разлику од тога, Хумболтово неуспело путовање за Русију тумачи као последицу великог обима политичких, административних и службених дужности које га спречавају да у познијим годинама врши прецизна мерења (2007: 713). Предности немачке културе и њени подвизи, њена научна достигнућа, упркос томе, не штите од непредвидивог животног тока.

Разматрања о руском пространству, „земља је толико апсурдно велика да даљине губе на значају“, као и покушај његовог разумевања уз помоћ рационалног категорисања када се „растојања растварају у апстрактну математику “ (280), указују на напор који се чини ради сагледавања културног предела. Рационални приступ подразумева смањење простора који покрете чини препознатљивим. Покрети, који опет премошћују простор, последично захтевају време. Келман редовно дописивање између два научника и размену идеја о њиховим пројектима смешта у време почев од овог путовања. ${ }^{4}$ Гаусово експериментално посматрање флуктуације земље, формулисане у Хумболтовој хипотези, изискује време, што се такође одражава на људски унутрашњи свет: „Свако ко је посматрао ову иглу, гледао је у унутрашњост света“ (272). Посматрајући процесе који се одвијају у складу са природно регулисаним процесима, Гаус ствара везу између човека и природе, која, према редоследу његовог света, представља слободу. Тога постаје свестан у тренутку када се сетио геодете Хумболта, који се у Русији суочава са границама унутрашњег поретка: „Први пут му је било жао Хумболта““

4 За разумевање исказа у вези са историјским односима који се успостављају између немачке културе према другим културама, садржаног у Келмановом роману, потребно је обратити пажњу на у овом раду описану наративну структуру и на начин на који се у фабулу уклапа размена писама између двојице научника. Наиме, за разлику од историјским сведочанствима потврђеног почетка размене писама од 14. јула 1804. године писмом Александра фон Хумболта упућеног Фридрху Гаусу (Bruhns 1877: 2), Келман однос између два научника у роману приказује превенствено кроз причу ьихове писмене размене, референцама грађеним на оба Хумболтова путовања. 
(274) Хумболт исто доживљава приликом размишљања о истраживачу законитости природе који је једва искорачио из најближег окружења: „Сиромах никада није видео ништа од света. Хумболт се меланхолично насмешио и одједном му је било жао Гауса“" (276).

\section{1. Русија у функцији хронотопа}

Поред Рикесовог тумачења епизоде у којој се евоцира идеја о успостављеној телепатској вези између Гауса и Хумболта, (2012: 87) исту је могуће посматрати и из угла Ајнштајнове категорије 'временског простора,' коју Морсон и Емерсон повезују са Бахтиновим хронотопом (Morson; Emerson 1990: 367). Мада је однос хронотопа према Ајнштајновом временском простору нешто слабији у стварању идентитетских обележја, у изражавању значења је, ипак, јачи од пуке метафоре или аналогије. На понуду места директора опсерваторије у кнежевини Брауншвајг Волфенбител Гаус од војводе додатно тражи звање професора на Универзитету у Хелмштету. Келманово поигравање са историјским подацима, како периодом постојања универзитета (1576-1810) тако и историјом немачких народа за време Наполеонове окупације, своје потпуно значење стиче између осталог и Гаусовим аргументом којим поткрепљује свој захтев, наиме, позивом на Санкт Петербуршку академију.

Пројекцијом руске културе, као словенске у функцији противаргумента, стварају се конотације које остављају утисак постојаног значења. Према томе, Русија се појављује у функцији хронотопа за изостало разматрање историјских односа, али и културних граница после Другог светског рата. У разговору са пруским војводом, Гаус изјављује да је Русија њега одувек занимала и да је често намеравао да научи руски језик, што потврђује амбивалентан однос немачке културе према руској као словенској. Значење се додатно јача његовим обећањем војводи да ће научити руски (146-7), као што је Хумболт експедицијом за Русију себи остварио дечачки сан. Колико је у овој епизоди садржано ироније или можда сарказма, говори наслов поглавља којем епизода припада, 'Звезде,' јер се наведеним тропима даје заправо дефиниција идеје о себи.

У интеракцији утисака пуних контраста, које је сакупио светски путник Хумболт, након путовања у Русију он одлучује да у своје путописе уврсти дугачко поглавље о томе (288). Међутим, његов контрахент Гаус ствара противтежу идејама глобалних погледа докторатом из области просторних концепата. Након што је за свој рад добио научна признања, ништа га не спречава да истражује нова подручја. Он би отишао можда далеко, али не би напустио кнежевину Хановер (88). Према томе, концепција романа супротставља два социолошка гледишта. Хумболтов приступ је глобалистички; његова „манија за мерењем одвела га је широм света, од Шпаније до Америке, а касније и у Русију,“ док Гаус „остаје код куће у обављању својих математичких, астрономских и истраживачких активности“" (Пајзер 2010: 132), регионално ограничен.

Тек када се суоче са културолошким разликама у цивилизацији, које би требало да буду истог (временског) порекла, Хумболтова истраживања конфигурације живог света попримају свој пуни смисао; заправо се баве процесима који захтевају време. Володин у сузама прати Хумболтово мерење Волге 
које му се учинило „као путовање кроз време, као да је смештен у историјску књигу (...)“( (275), алудирајући на благу словенску душу.

3. Хронотоп у приповедној структури у Келмановом роману Мапирање света

Приповедачку структуру романа Мапирағе света Данијела Келмана могуће је поделити у три сегмента. У том случају, тематски наратив се дели у два приповедачка оквира међусобно повезана унутрашњим приповедачким током (Kindt 2012: 368). Први оквир представља сусрет Хумболта и Гауса у Берлину 1828. године током годишњег конгреса Друштва немачких истраживача природе и лекара, који успоставља везу са друштвеним односима, док други оквир чини живот и пут обојице научника након сусрета. Унутрашњи приповедачки ток чине аналептички међусобно повезане животне приче обојице научника до њиховог сусрета.

Језгро аналептичне наративне технике у свакој животној причи опет је однос који сваког од протагониста додатно карактерише. Хумболтов однос према пратиоцу Еме Бонплану, с једне стране, и Гаусов према сину из другог брака, Евгенија, који га прати током посете конгреса Друштва немачких истраживача природе и лекара, с друге стране, преузимају, поред јасно исказаних карактерних особина хероја романа, улогу референтних тачака у њиховом животу које манифстују симболичке вредности. Протагонисти се појављују у функцији одражавања историјских дискурса о пруском прелазном стадијуму на путу формирања немачке националне свести. Међутим, њен развој се прати искључиво под утицајем с једне стране сталног тињања у француско-немачкиим односима и, са друге стране, односа између Немачке и Сједињених Америчких Држава. У контексту значења садржаног у наслову, свет традицијоналног културног порекла проширује се на почетак истраживачког обликовања новог света. Принципи потребни за успостављање реда, који су обликовани према начелу просторне перцепције, чине основу за перцепцију природе и њених манифестација.

Гаус „се више није губио, познавао је ово подручје боље од било кога другог, након што је све ово фиксирао на мапи. Понекад се осећао као да није само измерио подручје, већ је измислио, као да је то са њим тек постало стварност. [...] Ништа што је неко некада измерио није било или би икада могло бити као пре“" (268).

На нивоу наративне структуре дефинисане према Тому Кинту (Tom Kindt), унутрашњи приповедачки ток се може додатно поделити, наиме мапирањем света: Хумболдт мери унутрашњи свет, композицију, конституцију животних облика, док Гаус мери спољни облик, конфигурацију животног окружења које омогућава постојање. Изненађује да ово, у принципу, доводи до два различита резултата, који су у основи супротни ономе што научници истражују у свом приступу. Хумболтово мерење конституената света природе доводи до чињенице да је измерио спољни свет, простор: „Крај пута је на видику, мерење света је готово потпуно“ (238), закључује Хумболт током излагања на конгресу и развија идеје о перспективи научних дисциплина које треба оформити. Гаус, с друге стране, налази приступ унутрашњем свету и, на тај начин, доживљава потребу за временом, за шта је потребна дистанца. Ради сагледавања успостављених 
релација унутар или временске или просторне категорије, или, пак, између ове две категорије, дистанца је потребна, према наведеном примеру разумевања Русије као културног предела, у обема категоријама, како у временској тако и у просторној.

Међутим, док се прича о научницима развија из њиховог професионалног приступа животу, у фабули приповедачког тока унутар описаних приповедачких оквира који се аналептички испреплићу, време се дели на прво Хумболтово путовање које води у Амазонију и његово друго, у Русију. У овом приповедачком сегменту, у аналептички међусобно повезаним животним причама, Гаусова честа размишљања о Русији у различитим околностима и изостанак дефинитивне одлуке да се посвети руском језику или прихвати професуру на Санкт Петербуршкој академији, и подударају се са концептом Бахтиновог хронотопа у смислу унутрашње повезаности временских и просторних односа (Bakhtin 1990: 84). Изостанак Бахтинове коначне дефиниције концепта, Морсон и Емерсон (Morson, Emerson 1990: 366-7) објашњавају постојањем уводних напомена на које се надовезују наизменично конкретни примери и уопштавања. Резултат овако устројеног аналитичког поступка је, потом, могућност успостављања нових, међусобно повезаних значења проистекилх из претходне анализе. Слично је са Келмановом наративном концепцијом.

3.1. Хронотоп научне рационализације и наспрамна слика у књижевној генерализацији

Келманов Хумболт је декларисани Кантовац. На почетку путовања, Хумболт свог пратиоца, Француза Бонплана, затиче in flagranti у друштву са дамом. Приликом позивања на пристојност, међутим, Хумболт га пита да ли је икада читао Канта. Његов контрахент Гаус, након што је завршио своје капитално дело, Disquisitiones Arithemeticae (Истраживачко праћење аритметике), као младић је отпутовао у Кенигсберг, у посету познатом филозофу коме је доставио копију својих истраживања. Пошто је детаљно објаснио сложену хипотезу књиге, Кант у непосредном одговору моли свог слугу Лампеа да купи неке „кобасице и звезде“ (97). Утисак банализације водећег филозофског ума немачког просветитељства како позивањем на њега у деликатној атмосфери тако и поистовећивање народне кухиње и Гаусових научних успеха од самога Канта Келман релативизује позивањем на везу између Кантових епистемолошких претпоставки и Гаусовоих истраживања законистости у природи. Ова веза наводи Бернхарда Шолца (Bernhard Scholz) на тезу којом упоређује научни приступ природно-математичких наука и књижевности. Проширујући Кантову идеју, Шолц науку дефинише као „,акт обликовања и изнуђивања природе“, док су у књижевности, посматране као корпус текстова, представљене „верзије природе које су осмишљене и изнуђене у складу са одређеним принципима“. Књижевност као историјски феномен, попут старијих фаза науке, је, каже Шолц, „складиште седиментираних нацрта за одговоре на императивна питања разума“"(2003: 155).

У овом контексту су приметне занимљиве аналогије. Наиме, док је Кант покушавао да научно утемељеним приступом стекне увид у универзални си- 
стем људске перцепције, Келманови прикази праћени кроз време и простор, потврђују оно што Бемонгова дефинише као Бахтинову тезу о историјским доказима у перцептивној активности, која се манифестује у књижевним текстовима (Bemong 2010: 3). Примера ради, када Хумболт тврди да разумевағе обликује природне законе, а Гаус на то одговара да је то стари Кантовски нонсенс, „разум ништа не обликује и мало разуме. Простор се савија, а време се растеже“ (220). постаје јасно, каже Џон Пајзер, да Келман симпатише Гаусово схватање које се легитимише негирањем Канта и просветитељства (Pizer 2010: 133). За разлику од Келмановог приступа, Бахтин конкретним примерима поткрепљује посредне показатеље коришћене у песништву. Описујући Гетеово путовање у Италији и обилазак Сицилије, он илуструје Гетеово разумевање историчности које стриктно одбацује „неприлично призивање древних авети“ (das fatale Hervorrufen solcher abgeschiedenen Gespenster). Приликом обиласка околине Палерма са водичем и његовог подсећања на Ханибалове битке које су овде вођене, Гете просто не види стваралачку (историјски продуктивну) везу између обрађених поља, њиховог обиља и сећања на топот Ханибалових слонова и коња (Бахтин 2013: 33). Закључке које Гете доноси на основу доживљаја и утисака, дефинишу категорију историчности која никако не може бити мешање прошлости и садашњости. У том смислу, Морис (Morris 1994) хронотоп посматра као когнитивни концепт, али и као „наративну карактеристику текстова“ (1994: 246). Морсон и Емерсон, са своје стране, генеричке хронотопе схватају као „саставни начин разумевања искуства и основу за визуелизацију и представљање људског живота“ (1990: 375). Исправност њиховог налаза потврђује Бахтинова констатација, према којој „Гете пре свега тражи и налази видљиво кретање историјског времена, неодвојиво од природне ситуације (Localität 2013) и свеукупност свих објеката које је човек створио, битно повезаних с том природном ситуацијом“ (2013: 34). Поредећи Бахтинову дефиницију улоге историјских података коришћених у фикционалној књижевности са Келмановом релативизацијом историографске тачности, долази се до закључка о нејасно разграниченим категоријама код Келмана, наиме, историје као категорије прошлости и историзма као културне категорије. Резултат тога је стварање наспрамне слике: „Ово није дивљина, рече командант. Ово је Русија“ (269).

\section{2. Наспрамне слике и хронотоп}

Приликом разматрања идеје о наспрамним сликама примећује се такође блискост са Бахтиновом аргументацијом. Због различите терминолошке употребе у теоријама књижевности на различитим језицима, дефиниције и разумевање Бахтинових категорија навело је међународну научну заједницу да користи мноштво различитих термина у намери да означи хронотопске књижевне појаве на различитим нивоима апстракције: говори се о „мањим“ и „главним“ хронотопима, „хронотопским мотивима“ и „хронотопима читавих жанрова,“ (Морсон; Емерсон 1990: 374) „мотивским“ и „генеричким“ хронотопима, (Keunen 2000) „основним“ и „суседним“ (Vlasov 1995: 44-5) или о „микро-“, „случајним“, „локалним“ и „главним“ хронотопима. (Ladin 1999) Међутим, у немачкој теорији књижевност ретки су радови на тему хронотопа и држе се и даље описног оквира дефинисаног још од Вегнера (Wegner 1989; Dennerlein 2009). Пажњу привла- 
чи, у одређеној мери, идеја о просторној промени, као и тополошкој промени (енглески spatial turn), која се од краја 1980-их година појављује као парадигматска промена у културологији и социјологији. Међутим, термин није успео да се наметне у немачкој науци о књижевности јер је немачка терминологија окренута идеји о грађи (Stoff) и мотивима. Ипак, повремено се користи израз "сиже," који се сматра сродним (Klein 1993: 148).

С обзиром на историјски оквир романа Мапирање света, Бахтинова идеја о историјској поезији, сагледана истовремено помоћу генеричких хронотопа као „формално конститутивних категорија“ литературе, (1990: 84) може се, према Шолцу, разматрати у контексту „теорије о „причи “која ће бити осетљива на историјске промене“ (2003: 161). Као алтернатива наводно универзалној формалистичко-структуралистичкој опозицији између фабуле и сижеа (histoire vs. récit), Шолц генеричке хронотопе схвата као културно санкционисане принципе реда који могу створити типичне структуре деловања. При томе, он предлаже да се прича (fabula, histoire) подели у два нивоа: (1) „у концепт хронотопа који се односи на начела генерисања радње“ и (2) „у концепт структуре радње ради позивања на хронотопски низ догађаја који су уређени по овом принципу“" (ibid.: 163).

Друга карактеристика романа, мотив путовања, роман Мапирање света ставља у контекст Бахтиновог романа о искушењу, у којем се сиже гради на одступањима од нормалног животног тока јунака, на изузетним догађајима и ситуацијама каквних нема у типичној, нормалној, обичној човековој биографији (2013: 10). Иако у Бахтиновим дефиницијама није експлицитно одређен историјски роман, биографски ток романа о искушењу, идејом да увек почиње тамо где долази до одступања од нормалног друштвеног и биографског животног тока и завршава се тамо где живот опет улази у нормалан колосек, (ibid.) најпре одговара обележјима историјског романа.

Културни односи између Пруске и Русије у XIX веку били су изузетно блиски. Хано Бек (Hanno Beck) наводи писмо Хумболта, упућено 19. новембра 1827. године руском министру финансија, грофу Георгију Канкрину (Graf Georg v. Cancrin), у којем немачки научник износи своју „жарку жељу“ за пријемом код министра лично (2004: 23). Родбинске везе између владарских династија Пруске и Русије додатно су олакшале реализацију Хумболтовог путовања Русији. Међутим, које су се историјске промене током XX века догодиле и који је њихов значај по немачку културу, говори управо пример овог Хумболтовог путовања у Келмановој рефлексији историјских односа, с обзиром на искуство Немачке после Другог светског рата. Према Рикесу, шесто поглавље 'Река' представља својеврсни песнички суд о развојној странпутици немачке књижевности након 1945. године. У поглављу је описана пловидба чамцем по реци Рио Негро током које Александра фон Хумболта прате четворица домородаца иза чијих имена се крију четири велика јужноамеричка писца: Габријел (García Márquez), Хулио (Cortázar), Карлос (Fuentes) и Марио (Vargas Llosa). Код Келмана пресуда је недвосмислена и негативна: мада се у немачкој књижевности повремено појављују песнички успешни описи природе, послератну литературу у целости представља, могло би се рећи, удаљену од стварности. С једне стране, недостаје јој наративна снага великих аутора Латинске Америке, сматра Рикес, 
и с друге стране изгубила је приступ сопственој књижевној баштини (2012: 77). У овом случају, напред цитирани навод Михајла Бахтина о механичком мешању садашњости и прошлости, које је Гетеу без стварне везе са временом било крајње мрско (2013: 32), само потврђује Рикесов налаз. Приликом културног поређења, које служи идентификацији властитих културних обележја, успостављање дихотомије у случају грађења немачког идентитета могуће је препознати и у Келмановом роману, дуж европске линије цивилизацијских разлика између европског запада и источних односно словенских народа.

Штавише, рецепцијом Бахтиновог концепта створена је основа за препознавање интеркултуралне компетенције у херменеутичком приступу. У ту сврху, хронотоп поседује двојаку функцију. Према Боргхардовој дефиницији, прва функција означава да је хронотоп заснован, пре свега, на културним сведочанствима која упућују на друштвену стварност, док се у другој читалаштву преноси у одређеној мери стручна сазнања о актуелним друштвеним односима (2010: 79-80). Приликом одређивања конституената у књижевном дискурсу, налази у стручној литератури једним делом говоре о Бахтиновом повременом коришћењу израза хронотопа и мотива као синонима када, на пример, наизменично користи фразу „хронотоп састанка“ и „мотив састанка“ (Бахтин 1990: 97). Из тог разлога, Морсон и Емерсон хронотопе означавају или као мале или као хронотопске мотиве, док се код Бахтина наилази и на термин „мотивски хронотоп“ (Bemong 2010: 9). Ове, схваћене као „градивне блокове“ наративних текстова, Којнен (Keunen) дефинише као „четверодимензионалне менталне слике, комбинујући три познате просторне димензије са структуром временске радње“ (2001: 421). Морсон и Емерсон исте називају „прикривеним догађајима“, „кондензованим подсетницима временског и просторног типа“ (1990: 374). Интеракцију између ових мањих хронотопских елемената Бемонгова назива главним или доминантним хронотопима (2010: 7), док их Ладин дефинише као централне, „транс-субјективне“ хронотопе (1999: 215), који у наративном тексту служе обједињавању појединачних хронотопа.

У том смислу, Гаусово сећање на извесну Нину: „Она која му се највише свиђаше, звала се Нина и беше пореклом из далеког сибирског града“ (86), може се сматрати градивним материјалом, али хронотоп састанка, односно мотив састанка, за разлику од тога, састоји се од више таквих сегмената. До овог закључка долази се приликом описа друштвених односа који произлазе из Хумболтовог и Гаусовог разговора током заједничког састанка са пратиоцима. Позивањем на пруског краља Фридриха Вилхелма, у овом случају III, што у тексту није посебно назначено, у разговору се тематизује истраживање и помоћу паралеле успостављене са Наполеоновом експедицијом, доведеном у везу са темом путовања за Египат, епизода стиче своје значење тек одбијањем Хумболта да прихвати званичне позиве за посету Русији. Мера у којој Келман друштвене односе пројектује једне наспрам других, показује Хумболтов однос према владајућем друштвеном уређењу у Русији. Мада је њему било познато да друштвени односи, положај, надлежности и одговорности захтевају одговарајућу комуникативну форму, ${ }^{5}$ разлоге које наводи у тренутку послужења

\footnotetext{
${ }_{5}^{5}$ Рајнхард Андрес (Reinhard Andress) наводи писмо Александра фон Хумболта упућено
} 
чаја, сврставају културне односе, између оне Хумболтовог порекла као и оне домаћина, једне наспрам других: „-- поклон цара, чији министар финансија је њега редовно позивао у посету Русији. Подразумеваше се да је отказао из политичких разлога, али, наравно, и због својих година“ (218). Немачка свест о властитом историјском бићу осликана је у Хумболтовој перцепцији друштвених односа.

За Пајзера, Келманов Хумболт је очигледно збуњен и указује на границе просветитељске рационалности када је у питању разумевање културе, која се радикално разликује од данашње Западне Европе (2010: 131). Историјски, однос према култури у источном суседству означен је, штавише, културном нетрепељивошћу, када Гаус приликом посете Канту у Кенигсбергу слуша „чудне дијалекте“ и запажа „неразумљиве знакове“ или осећа да „из таверни не мирише на храну“ (94). Свакако, иронија којом се Келман у роману користи, поставља питање границе прихватљивог. Било да Хумболт говори о условима живота уместо о животним облицима, да ће се „бавити неживом природом, али односе нижих народних класа не би студирао“" (265), или о друштвени односима организованим према социјалном наслеђу људске егзистенције, Келман карикира друштвене односе према историјским стереотипима. Док његови пратиоци, помоћници рутински извршавају задатке, Хумболт вечера код гувернера, заједно са његова четири брата, осам синова, пет кћерки, неколико туца унучади и праунучади, те безброј рођака који би да слушају Хумболтове приче о прекоокеанској земљи. Међутим, Хумболтов одговор гласи: „Не би знао, једва се сећа и радо би отишао да легне“" (276).

Према Шлегеловом схватању ироније као филозофском симболу, иронија се састоји од знакова која служе сагледавању целине. Описујући Хумболтов сусрет са пруским краљем пред почетак експедиције за Русију, Келман наводи унапређење вишег дворског службеника Хумболта у тајног саветника. Звање екселенције треблао је да му олакша приступ зету пруског краља, руском цару Николају I Павловичу. У разговору представљеном као мучном, Хумболт своје расположење правда смрћу снаје Каролине. Пак, спомињањем родбинских веза и личним тоном разговора, Келман напушта историјски оквир, што, према Франку Холу (Frank Holl 2012), доводи до контрадикције између стварне историјске личности и Келмановог фиктивног карактера (2012: 61). Сегменти из Хумболтовог живота, који у роману нису споменути, као на пример путовање за Кубу и потом цензурисање његовог извештаја, скрећу пажњу са кључних друштвених питања, што Мартин Распер (Martin Rasper) сматра не само вређањем науке, него и читаоца (2017: 48). Иако су историјски детаљи прецизно коришћени у роману, управо пример помињања Фридриха Вилхелма без римске ознаке 6 указује на резултат добијен формирањем овог хронотопа. Наиме, вишезначним алузијама, које настају књижевном генерализацијом, политички се ангажман Хумболта, који се за живота залагао за људска права, пројектује у

дворском маршалу, које показује колико је Хумболт водио рачуна о форми писма и учтивим формулацијама. Томе додаје податак о дворској хијерархији у којој је дворски маршал могао бити подређен вишем дворском маршалу (2012: 8).

${ }^{6}$ У роману се не спомиње кумство Хуболтових са Фридрихом Вилхелмом II. 
наспрамнну слику изван историјског оквира, али се на тај начин истовремено заузима позиција и према Русији.

\section{Цитирана литература}

Бахтин, Михаил Михајлович. Естетика језичког стваралаштва. Сремски Карловци; Нови Сад: Издавачка књижарница Зорана Стојановића, 2013.

[Bahtin, Mihail Mihajlovič. Estetika jezičkog stvaralaštva. Sremski Karlovci; Novi Sad: Izdavačka knjižarnica Zorana Stojanovića, 2013]

Вукчевић, Миодраг М. ”Хумболтов сусрет са Амазонијом. Магични реализам у Келмановом роману Мапирање света“". [У:] Владимир Карановић, Анђелка Пејовић (ур.) Хиспанско наслеђе у мултикултуралном свету: зборник у част професору Далибору Солдатићу. Београд: Универзитет у Београду, Филолошки факултет, 2020, 277-296.

[Vukčević, Miodrag M. "Humboltov susret sa Amazonijom. Magični realizam u Kelmanovom romanu Mapiranje sveta“. [U:] Vladimir Karanović, Anđelka Pejović (ur.) Hispansko nasleđe u multikulturalnom svetu: zbornik u čast profesoru Daliboru Soldatiću. Beograd: Univerzitet u Beogradu, Filološki fakultet, 2020, 277-296]

Вукчевић, Миодраг М. Књижевност схваћена као социјални систем и контратекст. О комедијама Андреаса Грифијуса и Кристијана Ројтера. Београд: Филолошки факултет у Београду, 2013.

[Vukčević, Miodrag M. Književnost shvaćena kao socijalni sistem i kontratekst. O komedijama Andreasa Grifijusa i Kristijana Rojtera. Beograd: Filološki fakultet u Beogradu, 2013]

Andress, Reinhard. "Ein kurzer Brief Alexander von Humboldts an den Hofmarschall"“. Internationale Zeitschrift für Humboldt Studien 25, 2012: 5-10.

Bakhtin, Mikhail M. "Forms of Time and of the Chronotope in the Novel: Notes toward a Historical Poetics“. [In:] Holquist (ed.) Mikhail M. Bakhtin. The Dialogic Imagination: Four Essays. M. Austin: University of Texas Press, 1990, 84-258.

Beck, Hanno. Alexander von Humboldts Reise durchs Baltikum nach Russland und Sibirien 1829. Lenningen: Edition Erdmann, 2004.

Bemong, Nele et al. (eds.) Bakhtin's Theory of the Literary Chronotope. Reflections. Applications, Perspectives. Gent: Academia Press, 2010.

Borghart, Pieter and Michel De Dobbeleer. "Eulogizing Realism: Documentary Chronotopes in Nineteenth-Century Prose Fiction“. [In:] Bemong, N. et al. (eds.) Bakhtin's Theory of the Literary Chronotope. Reflections. Applications, Perspectives. Gent: Academia Press, 2010, 77-89.

Bumke, Joachim: Höfische Kultur. Literatur und Gesellschaft im Hohen Mitelalter. Band 1. München: dtv, 1986.

Dennerlein, Katrin. Narratologie des Raums. Berlin; New York: de Gruyter, 2009.

Ette, Ottmar. "Alexander von Humboldt in Daniel Kehlmanns Welt". Internationale Zeitschrift für Humboldt Studien 25, 2012: 34-40.

Gerstenberger, Katharina. 'Historical Space: Daniel Kehlmann's Die Vermessung der Welt“. [In:] J. Fisher, B. Mennel (eds.) Spatial Turns. Space, Place, and Mobility in German Literary and Visual Culture. Amsterdam; New York: Rodopi, 2010, 103-120.

Grabbe, Katharina. Deutschland - Image und Imaginäres. Zur Dynamik der nationalen Identifizierung nach 1990. Berlin; Boston: de Gruyter, 2014. 
Holl, Frank. "Die zweitgrößte Beleidigung des Menschen sei die Sklaverei ... Daniel Kehlmanns neu erfundener Alexander von Humboldt“. Internationale Zeitschrift für Humboldt Studien 25, 2012: 46-62.

Howell, James F. "The Hagiography of a Secular Saint: Alexander von Humboldt and the Scientism of the German Democratic Republic". German Quarterly 91/1, 2018: 67-82.

Keunen, Bart. "The Plurality of Chronotopes in the Modernist City Novel: The Case of Manhattan Transfer". English Studies 82/5, 2001: 420-36.

Keunen, Bart. "Bakhtin, Genre Theory and Theoretical Comparative Literature: Chronotopes as Memory Schemata“. [CLCWeb: Comparative Literature and Culture: a WWWeb Journal 2/2, 2000] < http://clcwebjournal.lib.purdue.edu> 4.12.2007.

Kindt, Tom. "Die Vermessung der Deutschen. Zur Reflexion deutscher Identität in Romanen Georg Kleins, Daniel Kehlmanns und Uwe Tellkamps“. Zeitschrift für Germanistik 22/2, 2012: 362-373.

Klein, Holger. "Autum Poems: Reflections on Theme as Tertium Comparationis“. [In:] W. Sollers (ed.) The Return of Thematic Criticism. Cambridge Mass.; London: Harvard University Press, 1993, 146-160.

Ladin, Jay."Fleshing Out the Chronotope“. [In:] Caryl Emerson (ed.) Critical Essays on Mikhail Bakhtin. New York: Hall, 1999. 212-36.

Morris, Pam (ed.). The Bakhtin Reader: Selected Writings of Bakhtin, Medvedev, Voloshinov. London; New York; Melbourne; Auckland: Edward Arnold, 1994.

Morson, Gary Saul and Caryl Emerson. Mikhail Bakhtin: Creation of a Prosaics. Stanford, CA: Stanford University Press, 1990.

Olesko, Kathryn M. "The World We Have Lost History as Art“. Isis 98/4, 2007: 760-768. Pizer, John. "Skewering the Enlightenment: Alexander von Humboldt and Immanuel Kant as fictional Characters". Atlantic Studies 7/2, 2010: 127-142.

Rasper, Martin."No Sports" hat Churchill nie gesagt. Das Buch der falschen Zitate. Salzburg; München: Ecowin, 2017.

Rickes, Joachim: Daniel Kehlmann und die lateinamerikanische Literatur. Würzburg: Königshausen \& Neumann, 2012.

Schaumann, Caroline. "Who Measures the World? Alexander von Humboldt's Chimborazo Climb in the Literary Imagination“. German Quarterly 82/4, 2009: 447-68.

Scholz, Bernhard F. 'Bakhtin's Concept of 'Chronotope': The Kantian Connection“. [In:] M. E. Gardiner (ed.) Mikhail Bakhtin 2. London: Sage, 2003, 145-72.

Tippelskirch, Karina von. "Paradigms and Poetics in Daniel Kehlmann's Measuring the World“. Symposium: A Quarterly Journal in Modern Literatures 63/3, 2009: 194-206.

Vlasov, Eduard.'The World According to Bakhtin: On the Description of Space and Spatial Forms in Mikhail Bakhtin's Works“. Canadian Slavonic Papers / Revue canadienne des slavistes 37/1-2, 1995: 37-58.

Wegner, Michael: "Die Zeit im Raum. Zur Chronotopostheorie Michail Bachtins“. Weimarer Beiträge 35/8, 1989: 1357-67.

Whitfield, John. "Opposites attract". Nature 445/15, 2007: 713-14.

Zschaler, Frank. "Die soziale Frage des 19. Jahrhunderts in deutscher und europäischer Perspektive“. [Im:] A. Habisch, H. J. Küsters, R. Uertz (Hrsg) Tradition und Erneuerung der christlichen Sozialethik in Zeiten der Modernisierung. Freiburg im Breisgau: Herder, 2012, 99-118. 


\section{Извори}

Bruhns, K. (Hrsg.) Briefe zwischen A. v. Humboldt und Gauss. Zum hundertjährigen Geburtstage von Gauss. Leipzig: Engelmann, 1877.

Kehlmann, Daniel. Die Vermessung der Welt. Reinbek: Rowohlt, 2008.

Schlegel, Friedrich. "Fragmente zur Poesie und Literatur". [Im:] E. Behler, J. J. Anstett, H. Eichner (Hrsg.) Kritische Friedrich-Schlegel-Ausgabe, 16/1. München; Paderborn; Wien; Zürich: Schöningh, 1981.

Schlegel, Friedrich. Philosophische Vorlesungen insbesondere über Philosophie der Sprache und des Wortes. Wien: Carl Schaumburg und Compagnie, 1830.

\section{Miodrag Vukčević}

\section{DAS GEGENBILD RUSSLAND ALS CHRONOTOPOS IN KEHLMANNS HISTORISCHEM ROMAN DIE VERMESSUNG DER WELT}

\section{Resümee}

Trotz des Bezugsreichtums in Daniel Kehlmanns vielbesprochenem Roman Die Vermessung der Welt fanden dessen Kapitel zu Alexander von Humoldts Russlanexpedition eine nur randständige Berücksichtigung in der erschließenden Literatur. Als Grund dafür kann das aus der historischen Erfahrung entwachsene deutsche Konzept der Gegenbilder angesehen werden, das unabhängig von Zeit und Raum in Beziehung zur Realität steht. In einen Zusammenhang zu Bakhtins Begriff „Chronotopos“ gesetzt, der diese beiden Kategorien zusammenführt, werden kulturelle Inhalte deutlich, die im gegenständlichen Werk ein Verhältnis der deutschen Kultur zur russischen als Gegenbild deutlich werden lassen.

Schlüsselwörter: Bakhtin M., interkulturelle Kompetenz, historischer Roman, Kehlman D., Die Vermessung der Welt, Gegenbilder, Vergangenheitsbewältigung, Chronotopos. 